\title{
"Se [...] vi venisse voglia di mutare per un po' di tempo la forma dell'architettura". II progetto dell'illusione di Andrea Pozzo in tre opere romane
}

\author{
Antonio Camassa \\ Matteo Flavio Mancini
}

\section{Abstract}

II presente contributo intende analizzare uno degli aspetti preminenti della poetica di Andrea Pozzo (1642-1709), con riferimento alle opere di quadratura: la sensibilità al contesto architettonico preesistente, ravvisabile nella modulazione di precisi parametri percettivi e progettuali.

Vengono presentati in questa sede i primi risultati delle indagini condotte su tre opere, di diversa tipologia architettonica e scala, riferibili al periodo romano di Andrea Pozzo: la Cappella della Vigna del Collegio Romano presso S. Balbina, il Corridoio delle stanze di Sant'lgnazio presso la chiesa del Gesù a Roma e la chiesa del Gesù di Frascati.

I rilievi fotogrammetrici e le conseguenti restituzioni prospettiche hanno permesso di individuare i punti di vista utilizzati da Pozzo e la volumetria delle architetture illusorie. Particolare attenzione è stata posta nel rintracciare, a partire dalle analisi geometriche, gli approcci progettuali alla base delle scelte percettive e architettoniche dell'artista sintetizzabili in tre categorie: allestimento con partiture architettoniche in prospettiva, sfondamento e addizione spaziale, trasmutazione anamorfica della forma.

I primi risultati della ricerca, da ampliare con l'analisi di ulteriori opere, restituiscono la figura di Andrea Pozzo progettista, capace di modulare le scelte progettuali sulla base delle caratteristiche spaziali e dei valori lessicali dell'architettura preesistente.

Parole chiave

Andrea Pozzo, quadraturismo, configurazione spaziale, trasformazione.
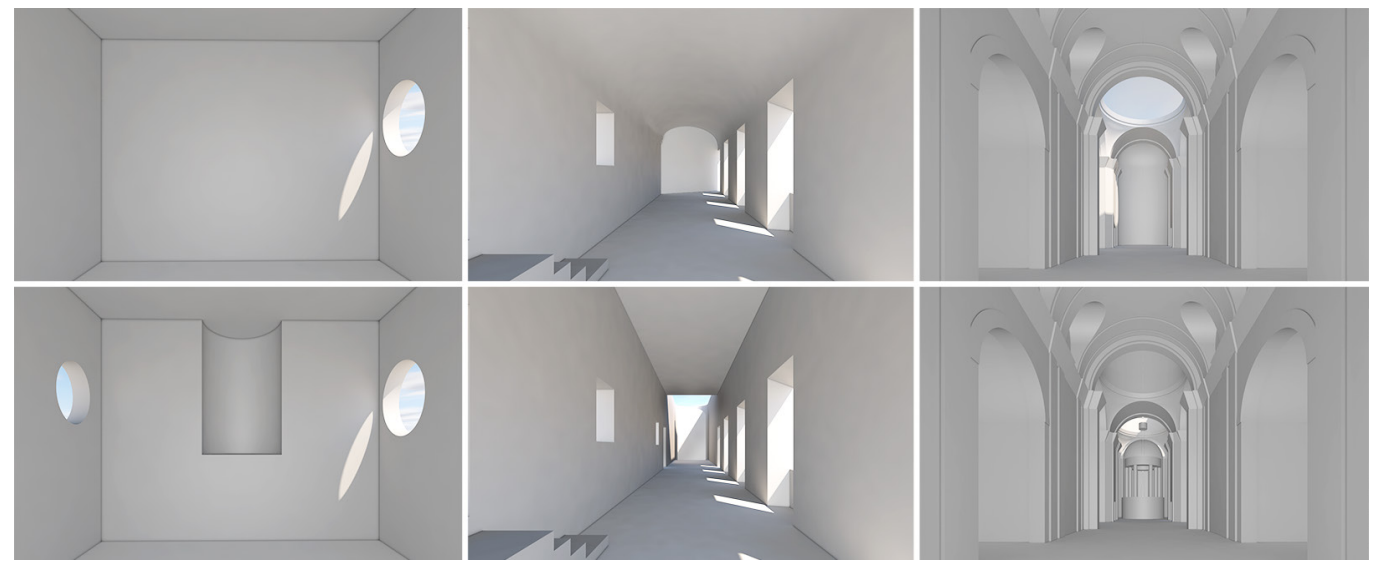
Uno degli aspetti preminenti della poetica di Andrea Pozzo ( I 642- I 709), con riferimento alle opere di quadratura, è la sensibilità con cui interviene all'interno degli spazi architettonici, attraverso la modulazione di precisi parametri percettivi e progettuali.

L'illusione generata sulle superfici, infatti, è frutto di un ragionamento spaziale [Battisti 1996] molto accurato che contempera il confronto lessicale con gli elementi architettonici presenti e una riflessione sulla forma dello spazio e sulla sua percezione, dai quali deriva il numero e la posizione dei centri di proiezione, in funzione degli obiettivi: allestire, dilatare, trasformare. Con l'obiettivo di rintracciare le ragioni progettuali all'interno del modus operandi con cui Pozzo procede nelle opere di quadratura, ovvero di come gestisca i parametri geometrici e gli aspetti formali al variare delle architetture reali, è stata avviata una analisi geometrica comparata delle sue opere.

In particolare, sono stati studiati tre interventi di quadratura del periodo romano di Andrea Pozzo, che va dal I68 I al I70 I: la Cappella della Vigna del Collegio Romano presso S. Balbina (fig. I a), attualmente Convento di Sant'Antonio alle terme (Roma, I 685) [Bösel, Salviucci Insolera 20 I0] [I], il Corridoio delle stanze di Sant'lgnazio presso la casa professa del Gesù (Roma, I685) (fig. Ib) e la chiesa del Gesù di Frascati (fig. Ic) (Frascati, I699-I70I). Le opere di quadratura selezionate riguardano tre diverse tipologie di spazio, quindi tre diverse scale d'intervento, e si configurano come tre diversi approcci progettuali rispetto alle architetture in cui sono inserite. In un caso l'intervento pittorico aggiunge elementi architettonici decorativi che ritmano le pareti con lievi aggetti, in un altro si ha una addizione dello spazio oltre i limiti reali e una trasmutazione anamorfica dell'architettura reale, nell'altro ancora lo spazio si dilata ampliandosi.

Lo studio è pertanto partito da un rilievo dello spazio reale, poi si è proceduto con la verifica dell'impostazione prospettica relativa alle opere di quadratura, per passare successivamente alla restituzione delle volumetrie progettate e dipinte.
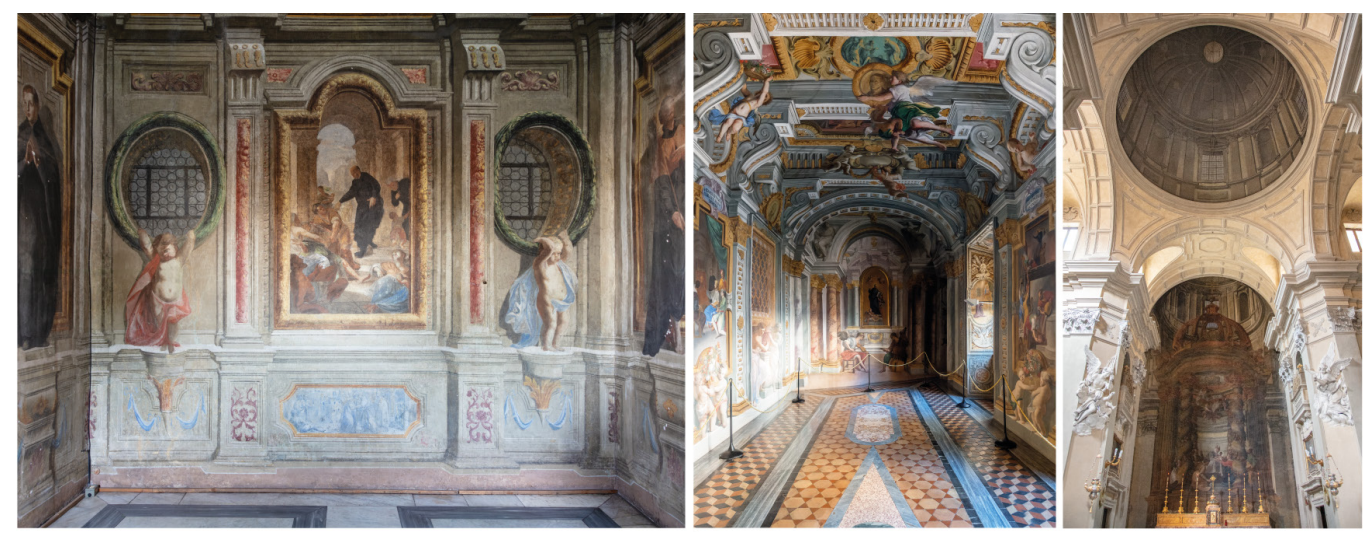

\section{Cappella della Vigna di Santa Balbina, Roma}

La Cappella della Vigna presso il convento di Sant'Antonio alle Terme a Roma è uno dei primi incarichi di Andrea Pozzo a Roma. II piccolo ambiente approssimativamente quadrato [2] misura 5,20 × 4,50 m [Gallavotti 1996] (fig. 2).

L'intervento di Pozzo riguarda le quattro pareti verticali e consiste in una decorazione architettonica, eseguita a tempera, che si limita alla definizione di partiture sulle superfici murarie, all'inserimento di una nicchia semicircolare sulla parete di fondo e all'apertura di due finestre ovali illusorie sulla parete sinistra, in tutto analoghe a quelle reali esistenti sulla parete opposta. II rapporto con il soffitto cassettonato è gestito da Pozzo attraverso l'inserimento di particolari capitelli-mensola, plausibilmente un riferimento architettonico di matrice nord italiana. All'interno delle partiture architettoniche a lesene vengono inseriti 
dei quadri incorniciati da modanature dorate analogamente a quanto avviene nel Corridoio delle stanze di Sant'Ignazio.

La struttura prospettica si basa su due centri di proiezione, entrambi dislocati lungo l'asse longitudinale della cappella a circa 1,60 m di altezza, tra l'ingresso e l'altare.

Una volta individuati il punto principale, l'orizzonte e la fuga dei piani verticali ortogonali al quadro di ciascuna parete è stato possibile ricostruire la posizione del primo punto di vista O come intersezione tra tre piani: il piano dell'orizzonte, comune alle quattro pareti, e i due piani meridiani verticali, ortogonali tra loro, che passano per coppie di pareti opposte (fig. 3 , a destra).Tale posizione è stata successivamente verificata attraverso la distanza principale desumibile dalla nicchia illusoria sulla parete di fondo. II punto di vista $O$, si trova in prossimità della porta d'ingresso e tiene pertanto conto della percezione di chi sia appena entrato e può abbracciare con un solo sguardo la parete di fondo e le due pareti laterali.

All'opposto, il secondo punto di vista $\mathrm{O}_{2}$ è collegato alla sola parete d'ingresso e, pur non essendo esattamente localizzabile a causa dell'assenza di elementi notevoli per la restituzione prospettica su tale parete, è riferibile con buona approssimazione alla posizione dell'officiante che accoglie chi entra volgendo lo sguardo verso l'ingresso. Intuitivamente, osservando l'analogia tra lo scorcio delle lesene della parete d'ingresso con quelle della parete di fondo, si può ipotizzare che la posizione di $\mathrm{O}_{2}$ sia simmetrica rispetto a $\mathrm{O}_{1}$ lungo l'asse longitudinale della cappella (fig. 3).

Fig. 2. Dettagli della cappella della Vigna: (a sinistra) un capitello-mensola; (a destra) un putto che sorregge un putto che
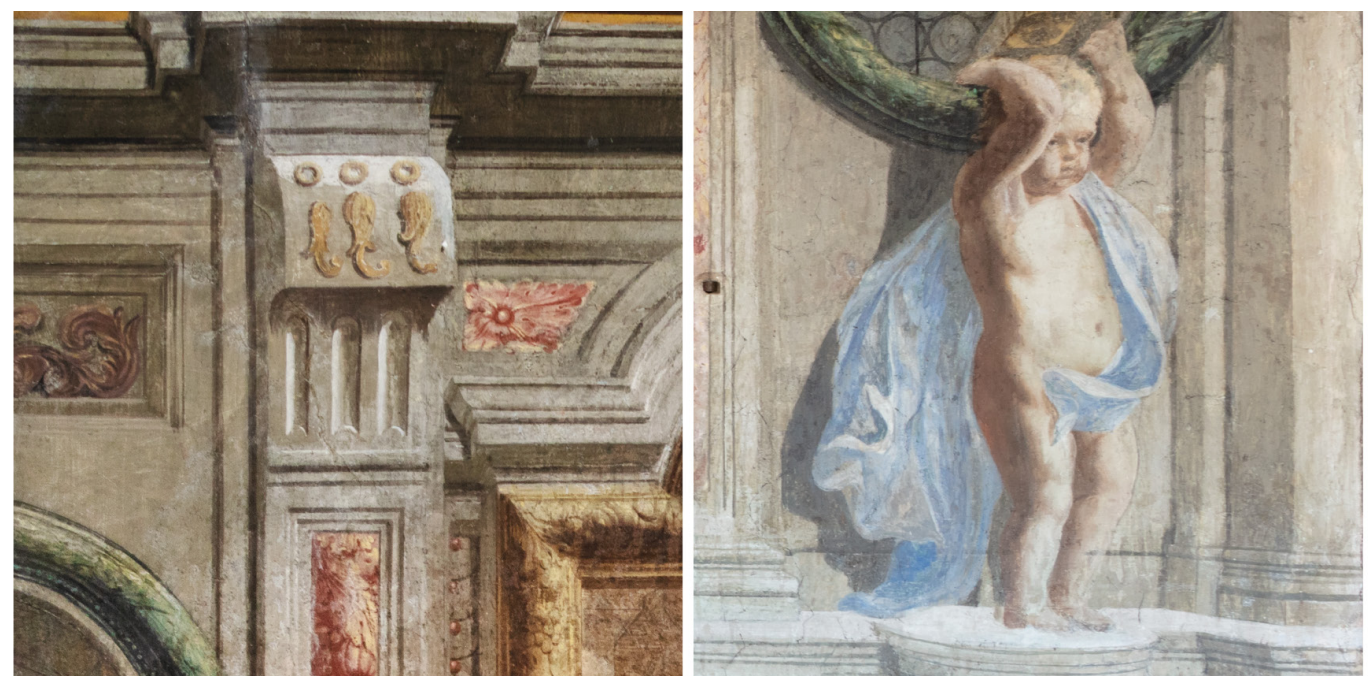

\section{Corridoio delle stanze di Sant'Ignazio, Roma}

Il corridoio delle stanze di Sant'|gnazio è un ambiente trapezoidale coperto da una volta a botte ribassata, di larghezza pari a circa 4,10 m e lunghezza variabile tra i 15,60 m del lato lungo minore e i $18,00 \mathrm{~m}$ del lato lungo maggiore, altezza compresa tra i 3,50 m all'imposta e i $4,75 \mathrm{~m}$ al cervello della volta.

L'intervento di Pozzo riguarda tutte le superfici dell'ambiente, le 4 pareti verticali e la volta a botte, oltre alla parete esterna d'ingresso. L'approccio compositivo adottato nel corridoio è decisamente più articolato di quello adottato nella cappella della Vigna anche se alcune assonanze possono essere rilevate nel trattamento pittorico della parete di ingresso e delle due pareti laterali caratterizzate dall'inserimento di partiture architettoniche. Dettagli comuni alle due opere sono inoltre la presenza di puttini a decorare le finestre e la morfologia delle cornici dorate che inquadrano le scene della vita di Sant'lgnazio (fig. 4).

In questo caso Pozzo non deve confrontarsi con un ambiente preesistente architettonicamente caratterizzato e pertanto opera in assoluta libertà, prevedendo operazioni compo- 
Fig. 3. Analisi prospettica della cappella della Vigna: (a sinistra) pianta con posizionamento dei punti $d$ vista e i ribaltamenti delle pareti affrescate; (a destra) vista assonometrica che illustra il procedimento adottato per l'individuazio ne del punto di vista $\mathrm{O}$ sitive differenti per ciascuna superficie. Sulla parete d'ingresso e le due pareti lunghe Pozzo interviene con l'inserimento di partiture architettoniche, nicchie e quadri mentre la parete di fondo presenta un'operazione di rettifica e sfondamento con l'addizione di uno spazio illusorio absidato che accoglie un ricco altare e amplia lo spazio reale rendendolo profondo circa il doppio di quanto in realtà non sia, ovvero circa 31,00 m. La volta infine subisce una vera e propria trasformazione anamorfica che la fa apparire come un soffitto piano sorretto da solide travi trasversali che inquadrano profondi cassettoni, portando inoltre l'altezza apparente a circa 5,80 m [3].

La struttura prospettica si basa, come noto, su un unico centro di proiezione la cui posizione è segnalata sul pavimento marmoreo ottocentesco. La sua altezza da terra [4], circa I,60 $\mathrm{m}$, è stata ricostruita seguendo la stessa procedura illustrata per la cappella della Vigna cui è stata aggiunta la restituzione dei piani proiettanti le travi affrescate sulla volta a botte. La ricostruzione ha confermato l'esistenza di un unico punto di vista per l'intera composizione. La posizione baricentrica di tale punto privilegiato porta il visitatore ad attraversare il corridoio andando alla ricerca del punto da cui tutta l'opera diventa fruibile senza distorsioni apparenti. Questa percorrenza lineare, che permette di apprezzare la trasformazione anamorfica dello spazio, si intreccia inoltre con quella anulare richiesta per la lettura delle scene della vita di Sant'Ignazio affrescate lungo le pareti. Pozzo istituisce così un doppio registro percettivo che guida l'esplorazione dello spazio.

Le dimensioni del corridoio lo rendono un ambiente decisamente particolare, facendolo certamente rientrare nella casistica degli ambienti 'bislunghi' per i quali Pozzo prescrive accorgimenti prospettici specifici, ovvero l'uso di un centro di proiezione e diversi punti della distanza [Pozzo 1700, fig. 56], che qui non appaiono però rispettati in favore di un maggior rigore prospettico forse indotto dall'importanza simbolica del luogo (fig. 5).
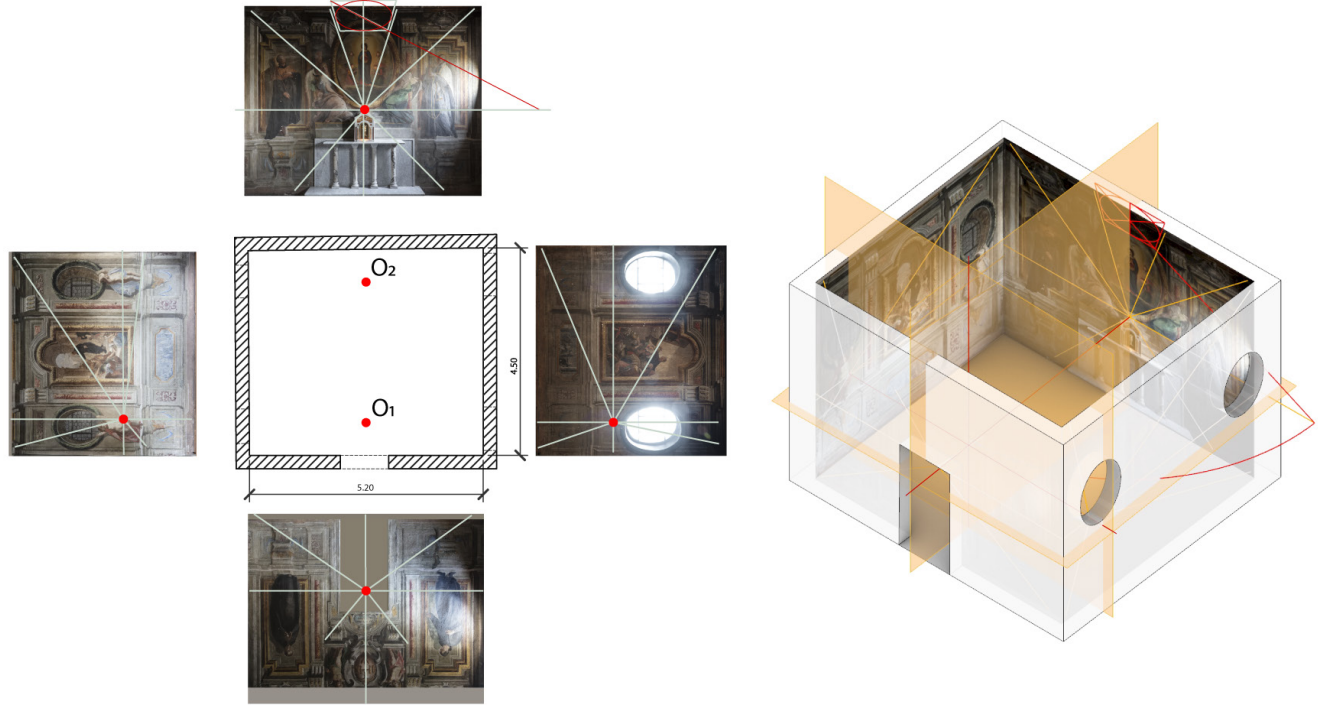

\section{Chiesa del Gesù, Frascati}

La chiesa del Gesù di Frascati, progettata nel 1694 da Gregorio Castrichini, fu ultimata - a meno della costruzione della cupola - nell'anno I70I [Pipita 2013]. Si presenta come un organismo architettonico complesso, a croce latina e navata unica di lunghezza pari a circa 33,00 m. L'imposta della finta cupola, che trova spazio nella crociera, misura 7,80 m di diametro, mentre la sua altezza da terra è di circa 14,50 m. La navata è animata dalla presenza di due cappelle laterali, anch'esse interamente affrescate dall'artista. II progetto dell'illusione, come nelle altre esperienze della stessa scala architettonica (nella chiesa della Missione di Mondovì e nella chiesa di Sant'Ignazio a Roma) sembra completare l'architettura in un eser- 
cizio retorico di mimesi che pervade tutta l'opera; ne sono l'emblema i due coretti affrescati negli altari del transetto (fig. 6), del tutto identici ai coretti reali, se non fosse per i mensoloni e la testa del putto nascosti dalla trabeazione dell'architettura illusoria.

Gli interventi progettati da Pozzo per la chiesa sono numerosi e tendono principalmente a operazioni di addizione spaziale [5]. La realizzazione delle quadrature, in virtù della complessità dell'impianto prospettico, venne eseguita dagli aiuti, come accade in numerosi cantieri dell'artista, primo fra tutti Antonio Colli, che dipinse la finta cupola piana su disegno di Pozzo nel I70I [Carta 1996]. Come accennato, il transetto ospita due altari dipinti in prospettiva, quello di destra dedicato a Santi Sebastiano e Agnese, il sinistro dedicato a San Francesco Borgia. In entrambi, l'architettura illusoria completa quella reale aggiungendo una finestra nell'altare di destra, analogamente a quella presente nell'altare di sinistra e completando in entrambi il gruppo di colonne in prospettiva a partire da quelle reali. L'abside - un cilindro schiacciato - ospita invece un esperimento prospettico di notevole interesse: Pozzo dise-

Fig. 4. Dettagli del corridoio delle stanze di Sant'gnazio: (a sinistra) un capitello; (a destra) un putto che sorregge una cornice.
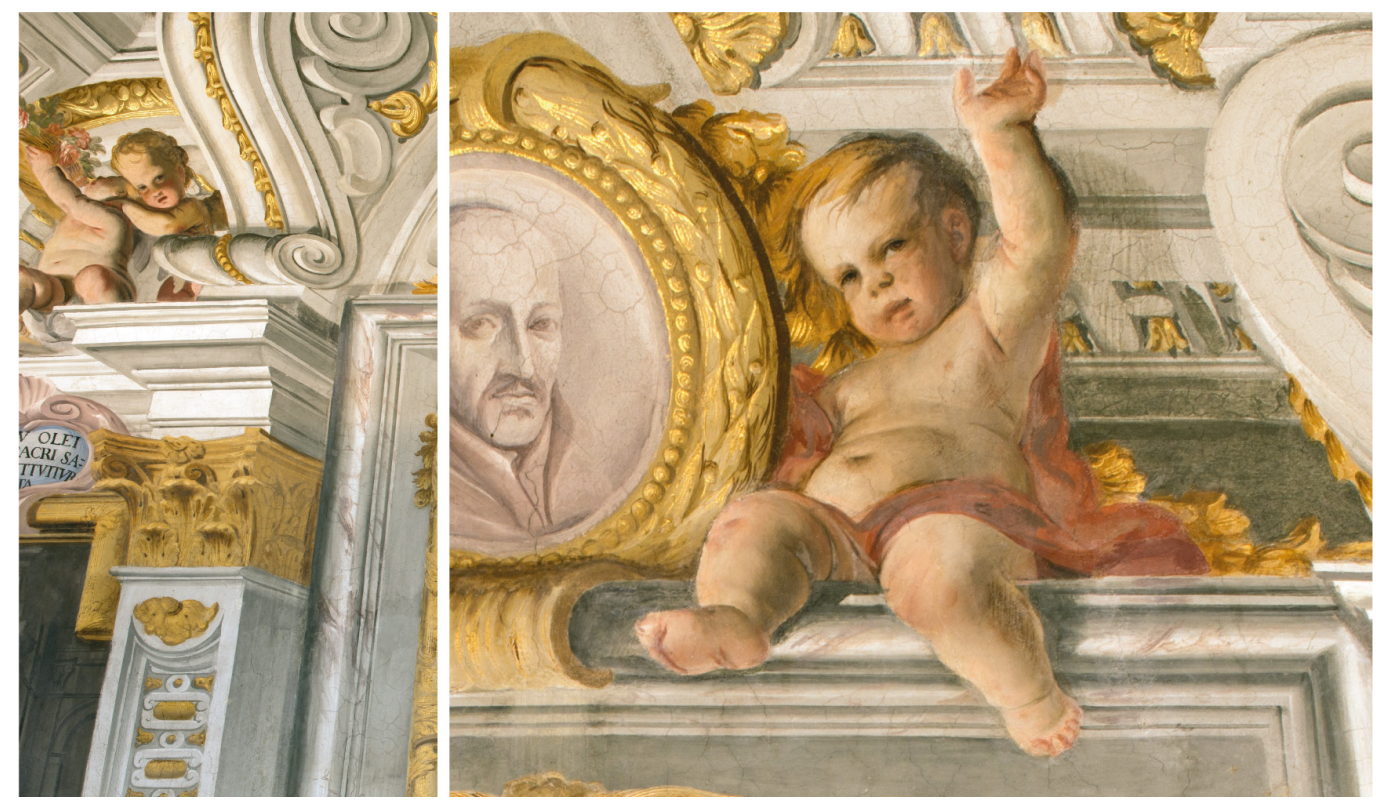

gna una prospettiva sulla superficie concava simulando l'aggiunta di una nuova crociera e un'ulteriore finta cupola all'imposta. La calotta intradossale di quest'ultima, accennata nella curvatura, è sorretta da un tamburo del tutto paragonabile alla finta cupola ospitata nella crociera (fig. 6). La restituzione prospettica ha messo in luce quanto la crociera affrescata da Pozzo nell'abside risulti confrontabile, in termini dimensionali e stilistici, alla crociera presente nella chiesa. In questo caso, quindi, la quadratura riproduce lo spazio che il fedele ha già attraversato, doppiando l'architettura reale e quella dipinta nella finta cupola, in un gioco arguto di continui rimandi alla dimensione fisica e a quella illusoria.

Lo sfondato proiettato nell'abside si completa con l'inserimento nella crociera dipinta di un baldacchino di invenzione, a pianta circolare, "sì che paresse convesso, mentre in realtà egli era al contrario" [Pozzo I700, fig. 69]. II baldacchino, finemente allestito con colonne tortili e gruppi di triple colonne presenta l'inserimento di figure intente alla celebrazione, con il risultato di risolvere la complessità dei piani di profondità.

L'impianto prospettico prevede la presenza di due centri di proiezione, uno per la finta cupola e uno per l'abside e i due altari nelle pareti del transetto. La scelta di collocare un centro di proiezione valido sia per l'abside sia per gli altari, al nadir della finta cupola [6], permette di capire meglio l'attenzione di Pozzo non solo agli aspetti formali dell'architettura, ma anche alla percorrenza dello spazio reale, quindi alla sua fruizione attraverso tappe percettive in un racconto architettonico totale. 
Fig. 5. Analisi prospettica del corridoio delle stanze di Sant'lgnazio: (a sinistra) pianta con posizionamento del punto di vista e ribaltamenti delle pareti affrescate: (a destra) vista afrescate; (a destra) vista assonometrica che illustra per l'individuazion punto di vista $O$.
Fig. 6. Dettagli della chiesa del Gesù di Frascati: (a sinistra) un balconcino reale (in alto) e uno illusorio (in basso); (a destra) il tamburo della cupola affrescato nel catino absidale (in alto) e quello dipinto della finta cupola della crociera (in basso).

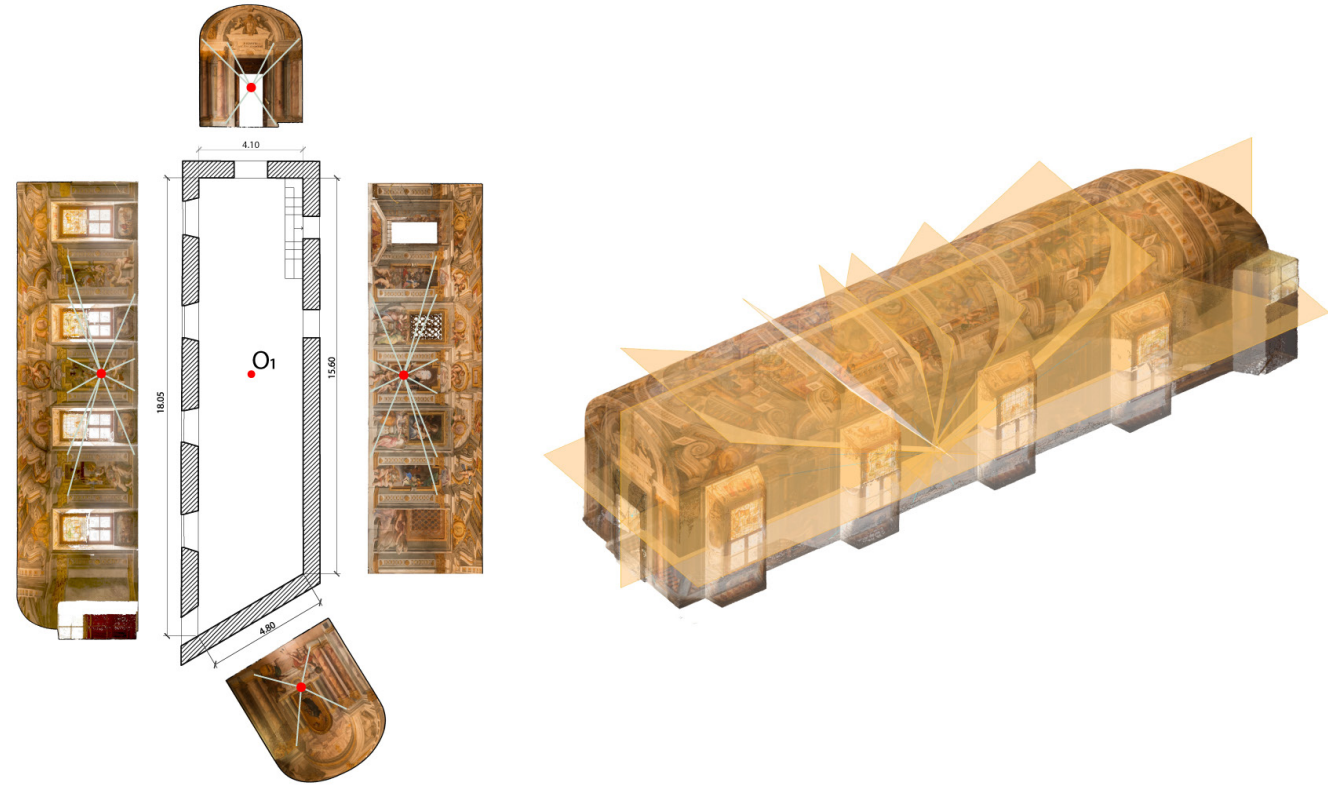

La restituzione prospettica della finta cupola, ottenuta ripercorrendo a ritroso il metodo che Pozzo descrive nei due volumi del Perspectiva pictorum et architectorum, ha consentito di individuare, nelle linee essenziali, la volumetria della cupola aggiunta all'architettura reale. II tamburo appare piuttosto slanciato a detrimento della calotta che invece risulta notevolmente schiacciata.

Le indagini relative alla calotta absidale sono partite dalla descrizione che Pozzo ne fa nella figura sessantesimanona del secondo volume del Trattato. Si è proceduto, sulla base del rilievo fotogrammetrico, all'individuazione delle curve sghembe sulla superficie della calotta che, attraverso la proiezione dal punto di vista ipotizzato al centro della crociera, sono state riportate sul piano di quadro posto all'intersezione tra abside e transetto (fig. 7). Le ellissi così ottenute sono state oggetto della restituzione prospettica che ha permesso la ricostruzione tridimensionale dell'ambiente e confermato la posizione del punto di vista al centro del transetto.
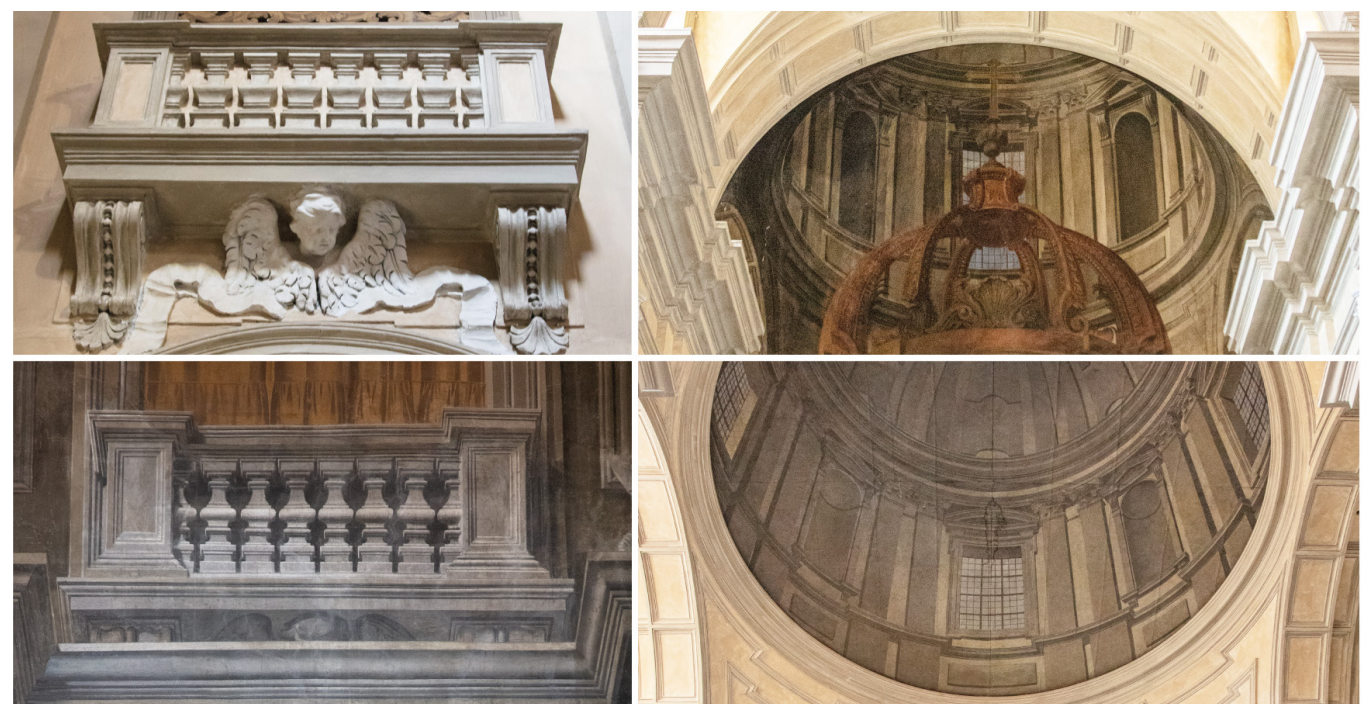
Fig. 7. Analisi prospettica della chiesa del Gesu di Frascati: (a sinistra) pianta con posizionavista e i ribaltamenti de prospetti; (a destra) vista assonometrica che illustra il procedimento adottato per l'individuazione dei punti di vista.

Fig. 8. L'unione tra spazio reale e spazio illusorio (in azzurro) nei tre casi analizzati: la cappella della Vigna (a); il corridoio della stanze di Sant'|gnazio
(b); la chiesa del Gesù di Frascati (c).
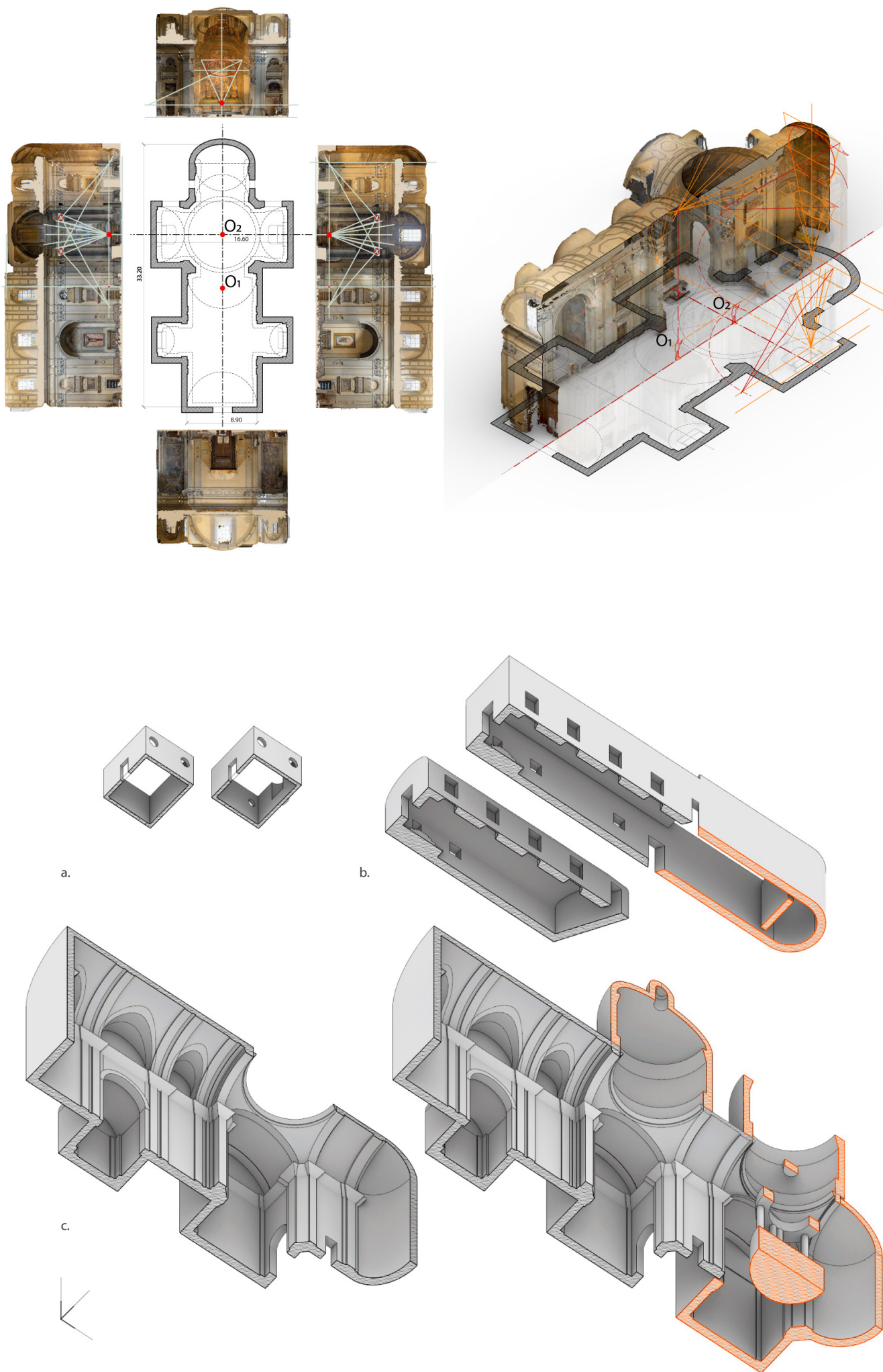


\section{Conclusioni}

Le analisi condotte sulle tre opere restituiscono la figura di un artista più versatile di quanto non emerga considerando le singole esperienze artistiche. Pozzo, infatti, appare in grado non solo di progettare architetture illusorie compositivamente e stilisticamente appropriate per i diversi ambienti in cui è chiamato a operare, ma anche di adattare l'impostazione prospettica di ciascuna illusione alle caratteristiche del luogo. Emerge infatti la capacità di variare l'impostazione delle quadrature utilizzando uno o più punti di vista, e di mettere in atto diverse operazioni progettuali che di volta in volta instaurano un rapporto preciso tra architettura reale e architettura illusoria: un intervento rivolto alla sola superficie muraria nella cappella della Vigna; un intervento articolato, in cui l'impaginato delle superfici, gli sfondamenti che aprono ad addizioni spaziali e la trasmutazione anamorfica della forma dialogano in un continuum unitario nel Corridoio delle stanze di Sant'Ignazio; uno, infine, con molteplici sfondamenti e addizioni spaziali, oltre all'aggiunta di elementi decorativi altrimenti assenti, nel Gesù di Frascati [7] (fig. 8).

Queste considerazioni conclusive possono essere sinteticamente rappresentate in un grafico che mette in relazione i criteri di analisi considerati - tipologia dell'ambiente reale coinvolto, numero di punti di vista adottati e tipologia di intervento compositivo scelto da Pozzo - e integra altre opere dell'artista trentino attingendo dall'ampia bibliografia [8] [Bergamo, Calandriello 20 I9; Dardanello 20 I0; Vallespìn 20 I4; Russo 1996; Bösel, Salviucci Insolera 2009] (fig. 9). Il grafico evidenzia la varietà degli approcci geometrici e compositivi adottati da Pozzo con alcune costanti: l'adozione di più punti di vista nei soggetti di grandi dimensioni e l'introduzione di effetti anamorfico-trasformativi nel caso di soggetti voltati di ridotte dimensioni. Gli sviluppi dello studio intendono ampliare la casistica analizzata sottoponendo l'intero corpus di quadrature di Andrea Pozzo al metodo analitico qui esposto [9].

Fig. 9. Il grafico sintetizza intervorti tra scala di dei punti di vista e operazione compositiva operazione compositiva adottata tra le opere quadratura di Andre

Pozzo.

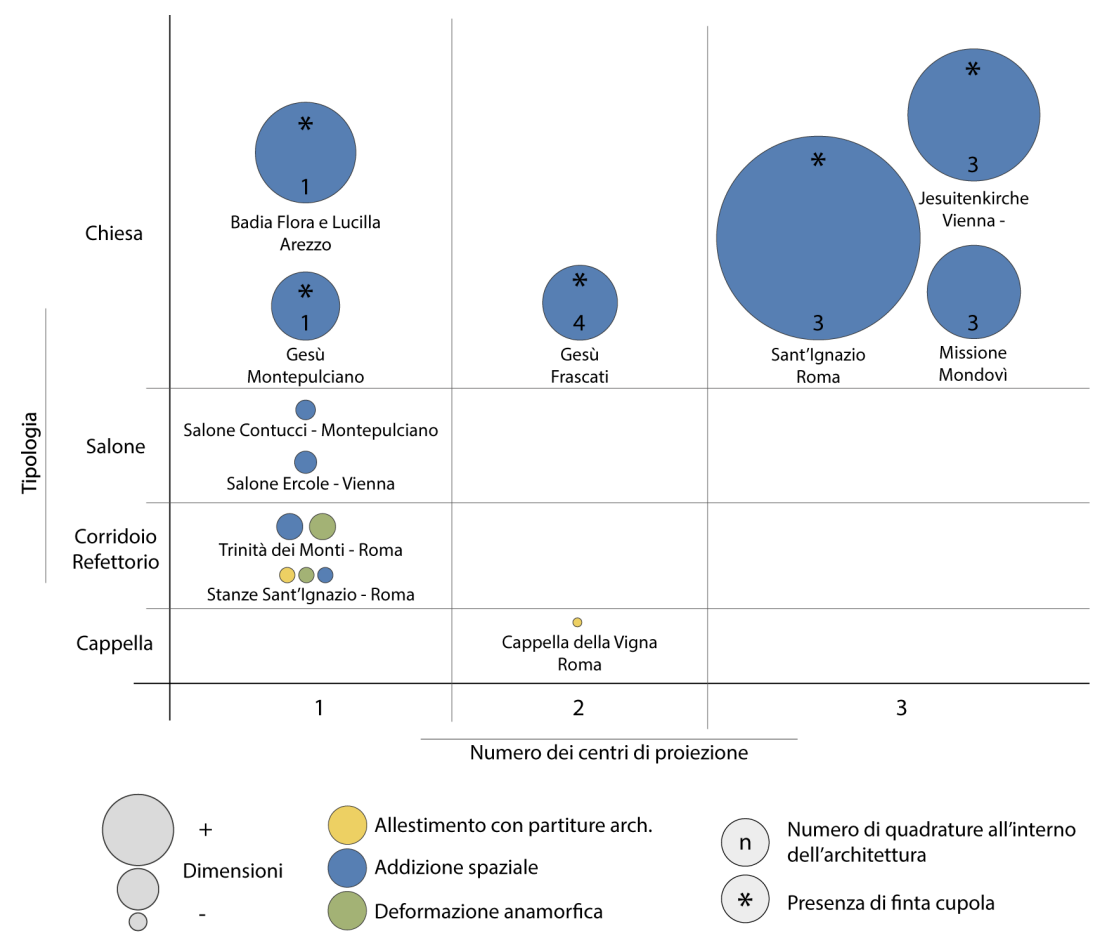

Note

[I] II convento, dopo la chiusura dell'Ordine gesuita nel I773, passò all'ordine dei Frati Minori Conventuali. Per aver permesso il rilievo fotografico e fotogrammetrico della cappella si ringrazia il guardiano padre Franklin e padre Campelo.

[2] La Cappella della Vigna rappresenta un luogo importante nell'agiografia Ignaziana; il Santo infatti avrebbe vissuto proprio in quella stanza gli ultimi giorni della sua malattia, prima di essere trasferito presso la casa del Gesù di Roma.

[3] Per una restituzione prospettica accurata dei singoli elementi architettonici e decorativi si veda: Romor 2019, pp.191-203: Sdegno, Romor 2008. 
[4] La restituzione prospettica dei principali elementi affrescati sulle superfici ha indicato un'altezza di I,56 m.

[5] Si riporta un estratto dalla biografia di F. Baldinucci: "impercioché essendo la chiesa molto corta, volle colla sua prospettiva farla apparire quasi per la metà piư lunga" [Benvenuti 1912, pp. 230].

[6] Scelta già operata nella chiesa di Sant'Ignazio a Roma.

[7] I modelli tridimensionali evidenziano i soli interventi che introducono modifiche nelle volumetrie degli ambienti. Gli elementi decorativi introdotti attraverso le quadrature non sono stati rappresentati per favorire una migliore lettura delle operazioni spaziali e compositive.

[8] Per la chiesa di Sant'Ignazio di Loyola vengono presi in considerazione tre centri di proiezione: uno per la Gloria di Sant'lgnazio, uno per la finta cupola e uno per il catino absidale. Per la chiesa del Gesù di Montepulciano sono stati presi in considerazione due centri di proiezione: uno per la finta cupola, uno per gli altari delle cappelle destra e sinistra. In quest'ultimo caso si precisa che nessun punto di vista preferenziale è indicato su pavimento.

[9] La citazione nel titolo è tratta dalla Figura Trentesimanona del primo volume del Trattato [Pozzo I693].

\section{Riferimenti bibliografici}

Battisti Alberta (1996). L'azione spaziale di Andrea Pozzo. In Battisti Alberta (a cura di). Andrea Pozzo. Milano-Trento: Luni Editrice, pp. 49-55.

Benvenuti Emilio (1912). La vita del Padre Andrea Pozzo scritta da Francesco Baldinucci. In AA.W. Atti della I. R. Accademia di Scienze lettere ed arti degli agiati in Rovereto, serie III, vol. XVIII, Fascicolo II. Rovereto:Tipografia Ugo Grandi, pp. 230.

Bergamo Francesco, Calandriello Antonio (2019). Andrea Pozzo e la quadratura del Refettorio: tra rigore prospettico e licenza poetica. In De Rosa Agostino (a cura di). Roma anamorfica: prospettiva e anamorfosi in epoca barocca. Roma: Aracne Editrice, Pp. $18-34$.

Bösel Richard, Salviucci Insolera Lydia (2009). Cronologia commentata della vita e delle opere di Andrea Pozzo. In Bösel Richard, Salviucci Insolera Lydia (a cura di). Mirabili disinganni. Andrea Pozzo (Trento I642-Vienna 1709). Pittore e architetto gesuita. Roma: Artemide, pp. 293-300.

Bösel Richard, Salviucci Insolera Lydia (a cura di). (2009). Mirabili disinganni. Andrea Pozzo (Trento 1642-Vienna 1709). Pittore e architetto gesuita. Roma: Artemide.

Carta Marina (1996). Le finte cupole. In De Feo Vittorio, Martinelli Valentino (a cura di). Andrea Pozzo. Milano: Electa, pp. 54-65.

Dardanello Giuseppe (2009). I2.07 Mondovì, Chiesa della Missione (g̣ià S. Francesco Saverio). Rilievo dell'architettura costruita e delle prospettive dipinte da Andrea Pozzo. In Bösel Richard, Salviucci Insolera Lydia (a cura di). Mirabili disinganni. Andrea Pozzo (Trento 1642 - Vienna 1 709). Pittore e architetto gesuita. Roma: Artemide, pp. 256-258.

Gallavotti Daniela (1996). Gli esordi pittorici a Roma: il corridoio del Gesù e la cappella della Vigna. In De Feo Vittorio, Martinelli Valentino (a cura di). Andrea Pozzo. Milano: Electa, pp. 42-53.

Migliari Riccardo (a cura di). (1999). La costruzione dell'architettura illusoria. Roma: Gangemi Editore.

Pipita Giuseppe (2013). La chiesa del Gesù a Frascati - Pitture di Andrea Pozzo. e-book LULU, 20 I 3.

Pozzo Andrea (1693). Perspectiva pictorum et architectorum, vol. I. Roma: Joannes Jacob Komarek.

Pozzo Andrea ( 1700). Perspectiva pictorum et architectorum, vol. II. Roma: Joannes Jacob Komarek.

Romor Jessica (2019). Andrea Pozzo e il corridoio della Casa Professa del Gesù. In De Rosa Agostino (a cura di). Roma anamorfica: prospettiva e anamorfosi in epoca barocca. Roma: Aracne Editrice, pp. I 9 |-203

Russo Maria (1996). Il salone delle Feste di Palazzo Contucci a Montepulciano. In Battisti Alberta (a cura di). Andrea Pozzo. Milano-Trento: Luni Editrice, pp. 28I-296.

Sdegno Alberto, Romor Jessica (2008). Percezione e restituzione degli affreschi di Andrea Pozzo presso le Stanze di S. Ignazio a Roma. In Disegnare Idee Immagini, n. 37, pp. 48-57.

Vallespín Muniesa Aurelio (20/4). La modificaciòn del espacio arquitectònico a través de la perspectiva: la intervenciòn de Andrea Pozzo en la iglesia de los Jesuitas de Viena. In EGA Revista de Expression Grafica Arquitectonica, n. I9, pp. 200-209.

\section{Autori}

Antonio Camassa, Università degli Studi RomaTre, antonio.camassa@uniroma3.it

Matteo Flavio Mancini, Università degli Studi Roma Tre, matteoflavio.mancini@uniroma3.it

Per citare questo capitolo: Camassa Antonio, Mancini Matteo Flavio (2020). 'Se [...] vi venisse voglia di mutare per un po' di tempo la forma dell'architettura". II progetto dell'illusione di Andrea Pozzo in tre opere romanel" "Se [...] vi venisse voglia di mutare per un po' di tempo la forma dell'architettura". The project of illusion by Andrea Pozzo in three Roman works. In Arena A., Arena M., Brandolino R.G., Colistra D., Ginex G. Mediati D., Nucifora S., Raffa P. (a cura di). Connettere. Un disegno per annodare e tessere. Atti del $42^{\circ}$ Convegno Internazionale dei Docenti delle Discipline della Rappresentazione/Connecting. Drawing for weaving relationships. Proceedings of the 42th International Conference of Representation Disciplines Teachers. Milano: FrancoAngeli, pp. 1017-1034. 


\title{
"Se [...] vi venisse voglia di mutare per un po' di tempo la forma dell'architettura". The Project of Illusion by Andrea Pozzo in Three Roman Works
}

\author{
Antonio Camassa \\ Matteo Flavio Mancini
}

Abstract

This contribution aims to analyse one of the preeminent aspects of Andrea Pozzo's (1642-1709) poetics, about the artworks of quadratura: the sensitivity to the pre-existing architectural context, recognizable in the modulation of precise perceptual and design parameters.

Here the first results of the investigations on three artworks are presented, with different architectural typologies and scales, referred to the Roman period of Andrea Pozzo: the Chapel of the Vigna of the Roman College at S. Balbina, the Corridor of the Rooms of Sant'lgnazio near the church of Gesù in Rome and the church of Gesù in Frascati. The photogrammetric surveys and the consequent perspective reconstructions made it possible to identify the points of view used by Pozzo and the volumetry of the illusory architecture. Particular attention was paid to tracing, starting from geometric analyses, the design approaches underlying the artist's perceptive and architectural choices, which can be summarized in three categories: superficial decorative intervention, opening and spatial addition, anamorphic transmutation of form.

The first results of the research, to be expanded with the analysis of further works, return the figure of Andrea Pozzo designer, able to modulate the design parameters based on spatial characteristics and lexical values of pre-existing architecture.

Keywords

Andrea Pozzo, quadraturismo, spatial configuration, transformation.

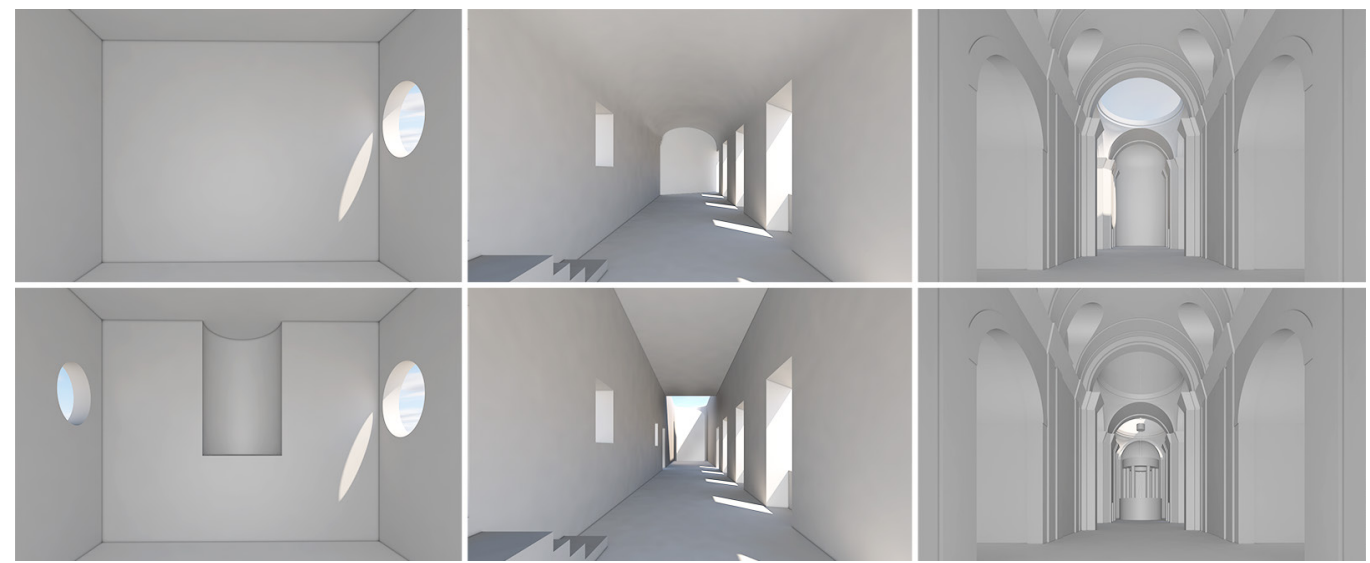


One of the preeminent aspects of the poetics of Andrea Pozzo (1642-1709), concerning the works of quadratura, is the sensitivity with which he intervenes within the architectural spaces, through the modulation of precise perceptual and design parameters.

The illusion generated on the surfaces is the result of a very accurate spatial reasoning (Battisti 1996) that considers the lexical comparison with the present architectural elements and a reflection on the shape of the space and its perception, from which derives the number and position of the projection centres, according to the objectives: set up, dilate, transform. To trace the design reasons within the modus operandi with which Pozzo proceeds in the works of quadratura, that is how he manages geometric parameters and formal aspects as the real architecture changes, a comparative geometric analysis of his artworks has been started.

In particular, three interventions of Andrea Pozzo's Roman period, from I68 I to I70 I, have been studied: the Chapel of the Vigna of the Collegio Romano at S. Balbina (fig. Ia), currently convent of Sant'Antonio alle Terme (Rome, 1685) [Bösel, Salviucci Insolera 20 I0] [I], the Corridor of the rooms of Sant'lgnazio a Casa professa of the Church of Gesù (fig. Ib) (Rome, I685) and the Church of Gesù in Frascati (fig. Ic) (Frascati, I699-I70I). The selected quadratura works concern three different types of space, therefore three different scales of intervention, and are configured as three different design approaches to the space where they are inserted. In one case the pictorial intervention adds decorative architectural elements that rhythm the space with slight overhangs, in another there is an addition of space beyond the real limits and an anamorphic transmutation of the real architecture, in the other the space expands and widens.

The study therefore began with a survey of the real space, then proceeded with the verification of the perspective setting relating to the works of quadratura, to then move on to the restitution of the volumes designed and painted.

Fig. I. Left wall of the chapel of the Vigna (a); the corridor of the rooms of Sant'lgnazio taken from the privileged point of view (b); presbytery and false dome of the church of Gesù in Frascati (c).
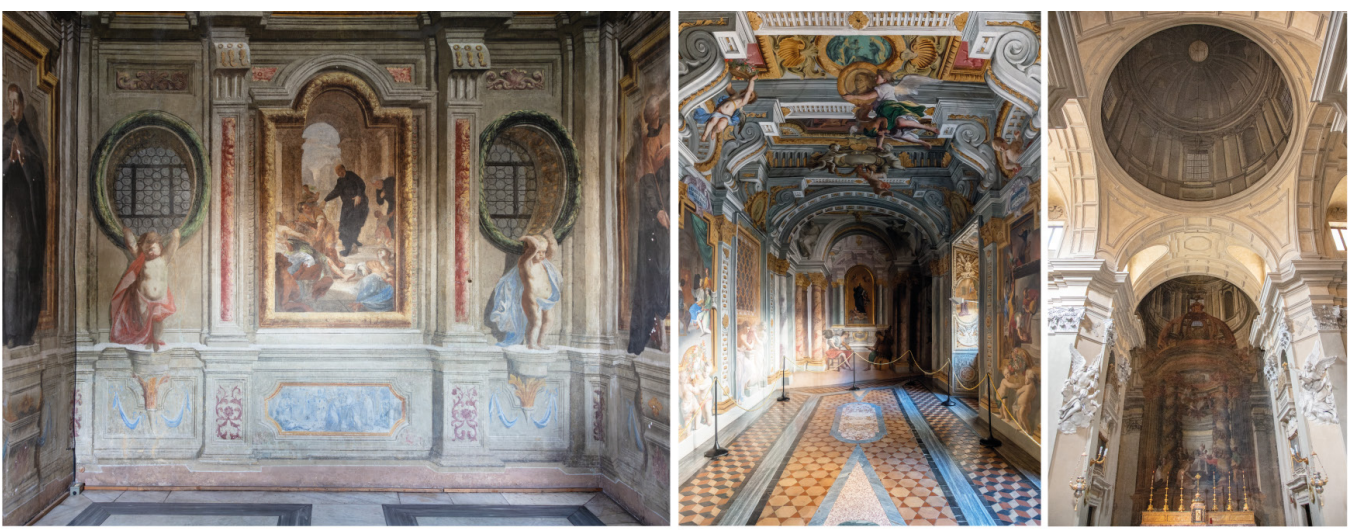

\section{Chapel of the Vigna di Santa Balbina, Rome}

The Chapel of the Vigna at the convent of Sant'Antonio alle Terme in Rome is one of Andrea Pozzo's first assignments in Rome.The small square room [2] measures approximately 5.20×4.50 m [Gallavotti 1996] (fig. 2).

Pozzo's intervention concerns the four vertical walls and consists of an architectural decoration, executed in tempera, which is limited to the definition of partitions on the wall surfaces, the insertion of a semi-circular niche on the back wall and the opening of two illusory oval windows on the left wall, all similar to the real ones existing on the opposite wall. The relationship with the lacunar ceiling is managed by Pozzo through the insertion of particular capitals-shelf, plausibly an architectural reference of northern Italian matrix. Between the pilaster strips architectural partitions, paintings framed by gilded mouldings are inserted, similarly to what happens in the Corridor of the rooms of Sant'lgnazio. 
The perspective structure is based on two projection centres, both located along the longitudinal axis of the chapel at a height of about $1.60 \mathrm{~m}$, between the entrance and the altar. Once the principal point, the horizon and the vanishing line of the vertical planes orthogonal to the picture had been identified on each wall, it was possible to reconstruct the position of the first point of view $O$ as the intersection between three planes: the plane of the horizon, common to the four walls, and the two vertical meridian planes, orthogonal to each other, passing through pairs of opposite walls (fig. 3, on the right). This position was subsequently verified through the main distance inferable from the illusory niche on the back wall. The $O$, point of view is located near the entrance door and therefore it takes into account the perception of the person who has just entered and can embrace the back wall and the two side walls with a single glance.

On the other hand, the second point of view $\mathrm{O}_{2}$ is connected to the entrance wall only and, although it cannot be exactly located due to the absence of remarkable elements for the perspective restitution on this wall, it is referable with a good approximation to the officiant position, which welcomes those who enter by looking towards the entrance. Intuitively, observing the analogy between the foreshortening of the pilasters of the entrance wall and those of the back wall, one can hypothesise that the position of $\mathrm{O}_{2}$ is symmetrical to $\mathrm{O}_{\text {, }}$ along the longitudinal axis of the chapel (fig. 3).
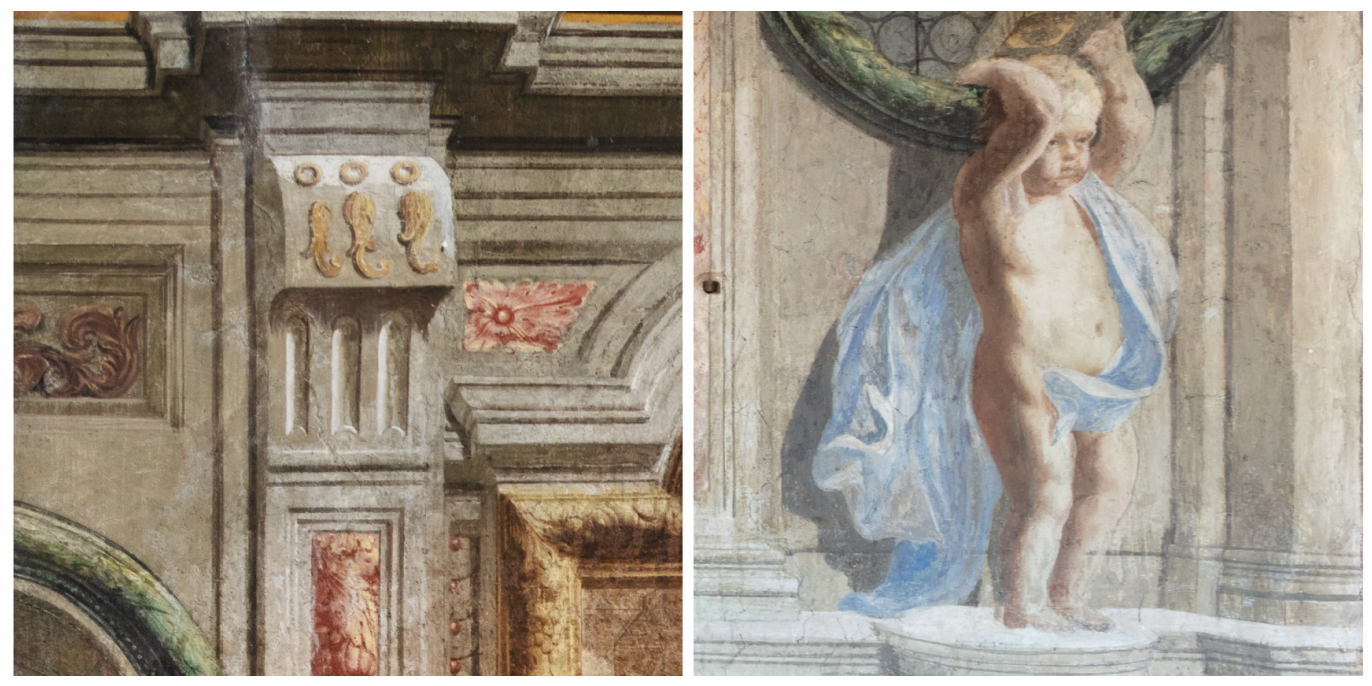

\section{Corridor of the rooms of Sant'lgnazio, Rome}

The corridor of the rooms of Sant'lgnazio is a trapezoidal room covered by a lowered barrel vault, about $4.10 \mathrm{~m}$ wide and variable length between $15.60 \mathrm{~m}$ of the shorter long side and $18.00 \mathrm{~m}$ of the longer long side, height between $3.50 \mathrm{~m}$ at the sets and $4.75 \mathrm{~m}$ at the top of the vault.

The intervention of Pozzo concerns all the surfaces of the room, the four vertical walls and the barrel vault, as well as the external entrance wall.The compositional approach adopted in the corridor is decidedly more articulated than that adopted in the chapel of the Vigna, even if some assonances can be detected in the pictorial treatment of the entrance wall and the two side walls characterized by the insertion of architectural partitions. The presence of cherubs decorating the windows and the morphology of the gilded frames, which frame scenes from the life of Sant'lgnazio, are also details in common to both the works (fig. 4). In this case, Pozzo does not have to deal with a pre-existing architecturally characterized space and therefore he works in absolute freedom, providing different compositional ope- 
Fig. 3. Perspective analysis of the chapel of the Vigna: (on the left) plan with the positioning of the points of view and the overturning of the frescoed walls: (on (the right) axon walls; (on ill dure adrated to identify dure adopted to identif rations for each surface. On the entrance wall and the two long walls, Pozzo operates with the insertion of architectural partitions, niches and paintings, while the back wall presents an operation of rectification and opening with the addition of an illusory apsidal space that houses a rich altar and enlarges the real space making it about twice as deep as it really is, that is about $31.00 \mathrm{~m}$. Finally, the vault undergoes a real anamorphic transformation that makes it look like a flat ceiling supported by solid transverse beams that frame deep coffers, also bringing the apparent height to about $5.80 \mathrm{~m}$ [3].

The perspective structure is based, as is well known, on a single projection centre whose position is marked on the 19th-century marble floor. Its height from the ground [4], about $1.60 \mathrm{~m}$, was reconstructed following the same procedure illustrated for the chapel of the Vigna to which the restitution of the projecting planes of the beams frescoed on the barrel vault was added. The reconstruction confirmed the existence of a single point of view for the entire composition. The barycentric position of this privileged point leads the visitor to cross the corridor in search of the point from which the entire work becomes viewable without apparent distortions. This linear path, which allows appreciating the anamorphic transformation of the space, is also intertwined with the annular one required for the reading of the scenes from the life of Sant'lgnazio frescoed along the walls. Pozzo thus establishes a double perceptual register that guides the exploration of space.

The dimensions of the corridor make it a decidedly particular space, making it certainly part of the case history of the 'bislong' spaces for which Pozzo prescribes specific perspective devices, i.e. the use of a projection centre and various points of distance [Pozzo 1700, Figure 56], which do not appear to be respected here in favour of a greater rigour in perspective, perhaps induced by the symbolic importance of the place (fig. 5).
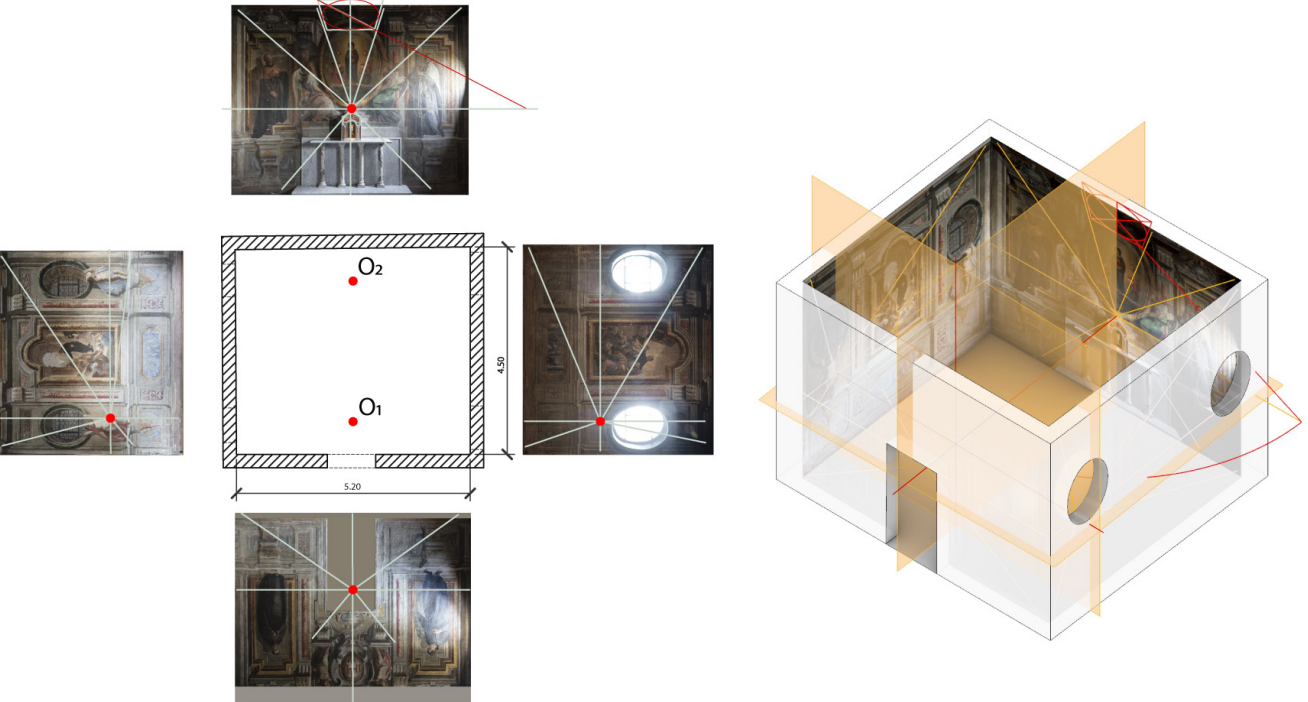

\section{Church of the Gesù, Frascati}

The Church of Gesù in Frascati, designed in 1694 by Gregorio Castrichini, was completed -without the dome- in the year I70I (Pipita 2013). It looks like a complex architectural organism, with a Latin cross and a single nave of about $33.00 \mathrm{~m}$ in length. The diameter of the false dome measures $7.80 \mathrm{~m}$, while its height from the ground is approximately $14.50 \mathrm{~m}$. The nave is animated by the presence of two chapels, also entirely frescoed by the artist. The illusion project, as in other experiences of the same architectural scale (in the Church della Missione in Mondovi and in the Church of Sant'lgnazio in Rome) seems to complete the architecture in a rhetorical exercise of mimesis that pervades the whole artwork; the 
emblem are the two choirs frescoed in the altars of the transept (fig. 6), completely identical to the real choirs, except for the corbels and the putto's head hidden by the entablature of illusory architecture.

The interventions designed by Pozzo for the church are numerous and tend mainly to spatial addition operations [5]. The realization of the quadratura works, for the complexity of the perspective layout, was also carried out by the aids, as happens in other artist's work sites. Antonio Colli painted the false flat dome based on Pozzo's design in I70I [Carta 1996]. As mentioned, the transept contains two altars painted in perspective, the one on the right dedicated to San Sebastiano and Agnese, the left dedicated to San Francesco Borgia. In both, the illusory architecture completes the real one by adding the missing window in the right altar, present instead in the left one, and completing the group of columns in perspective starting from the real ones. The apse -a flattened cylinder- hosts a prospective experiment of considerable interest: Pozzo draws a perspective on the concave surface simulating the

Fig. 4. Details of the corridor of the rooms of Sant'lgnazio: (on the left) capital; (on the right) a putto supporting a frame.
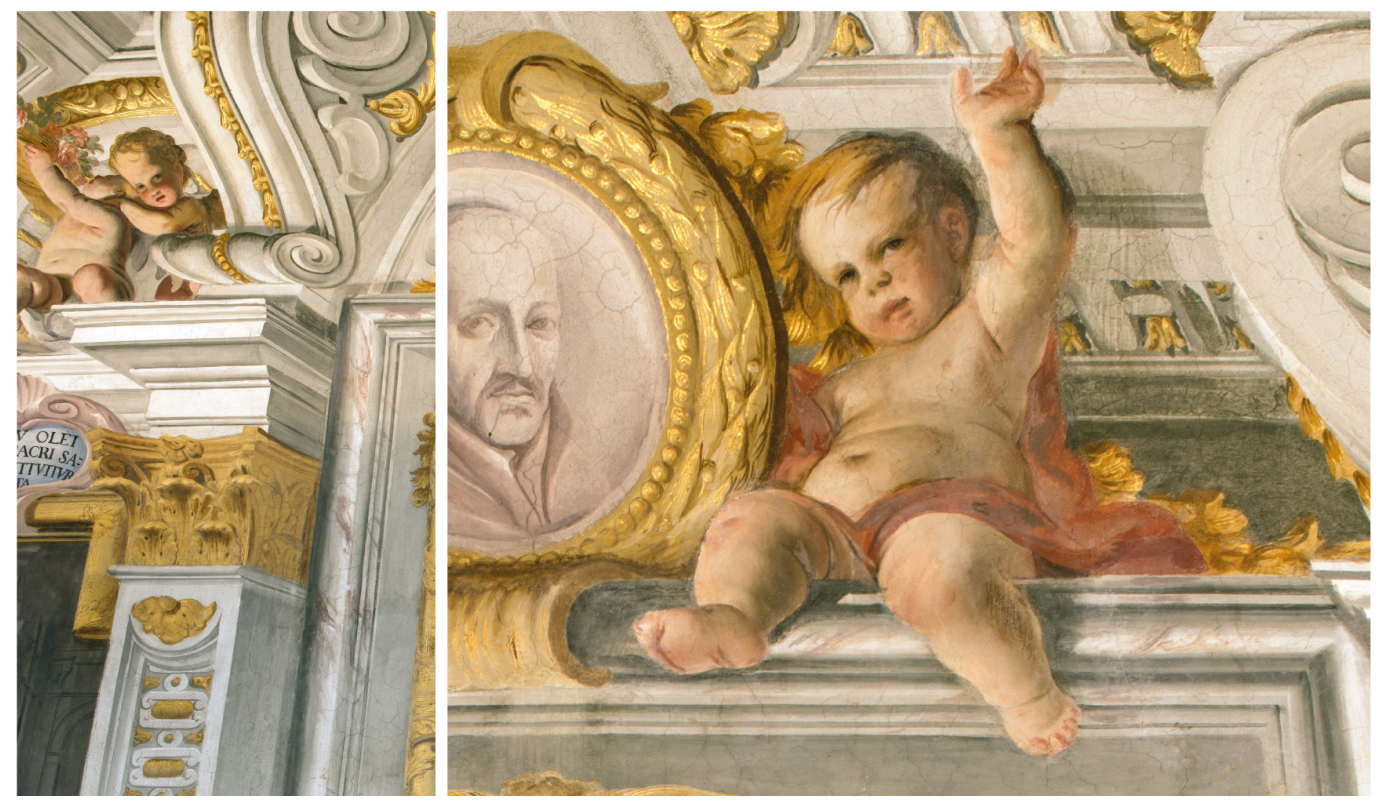

addition of a new crossing of the church and a further false dome. The intradossal cap of the latter is supported by a drum completely comparable with the false dome located in the real cruise (fig. 6). The prospective restitution has highlighted how the cruise frescoed by Pozzo in the apse is comparable -in size and style- to the real cruise in the church. In this case the quadratura reproduces the space that the visitor has already crossed, thus doubling the real architecture and the one painted in the fake dome, in a game ofarguzia and continuous references to the physical and illusory dimensions.

The perspective into the apse is completed with the insertion in the painted cruise of a circular baldachin of invention, "sì che paresse convesso, mentre in realtà egli era al contrario" [Pozzo 1700, Figure 69]. The baldachin, finely set up with twisted columns and groups of triple columns, presents the insertion of figures intent on the celebration, with the result of dissolving the complexity of the depth planes.

The perspective layout provides for the presence of two projection centres, one for the false dome and one for the apse and the two altars in the walls of the transept. The choice of placing a valid projection centre for both the apse and the altars, at the nadir of the false dome [6], allows us to better understand Pozzo's attention not only to the formal aspects of architecture, but also to the use of real space, therefore to its fruition through perceptive stages in a total architectural story. 
Fig. 5. Perspective analysis of the corridor of the rooms of Sant'Ignazio: (on the left) plan with positioning of the point of view and the overturning of the frescoed walls; (on the right) axonometric view illustrating the procedure adopted for the identification of the $O$, point of view.

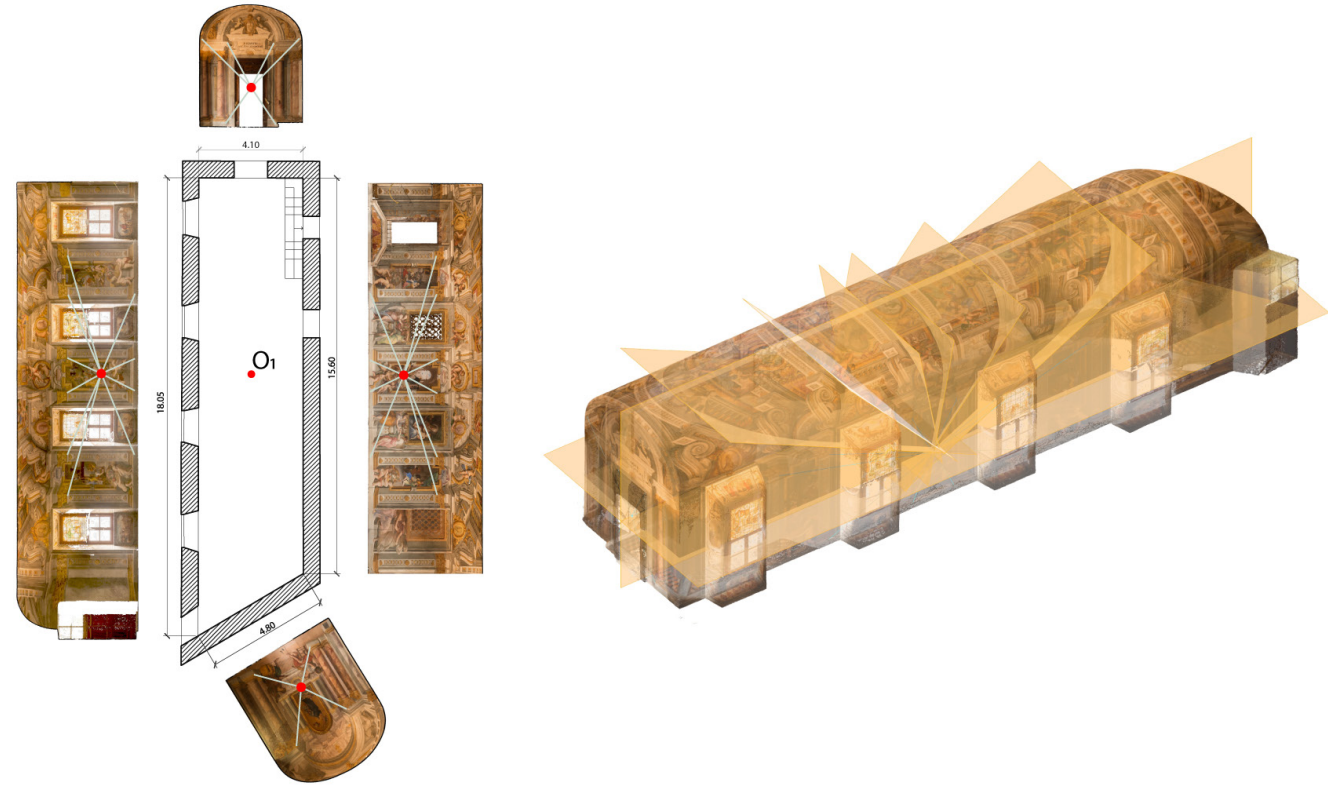

The perspective restitution of the false dome, obtained by retracing the method described by Pozzo in the two volumes of the Perspectiva pictorum et architectorum, has made it possible to identify in the essential lines the volume of the dome added to the real architecture. The investigations relating to the apse started from the description that Pozzo makes of it in the figura sessantesimanona of the second volume of the Treatise. Based on the photogrammetric survey, we proceeded to the identification of the skew curves on the surface of the cap which, through the projection from the point of view hypothesized in the centre of the cruise, were reported on the plane placed at the intersection between the apse and the transept (fig. 7). The ellipses thus obtained were subject to the perspective restitution which allowed the three-dimensional reconstruction of the environment and confirmed the position of the point of view in the centre of the transept.
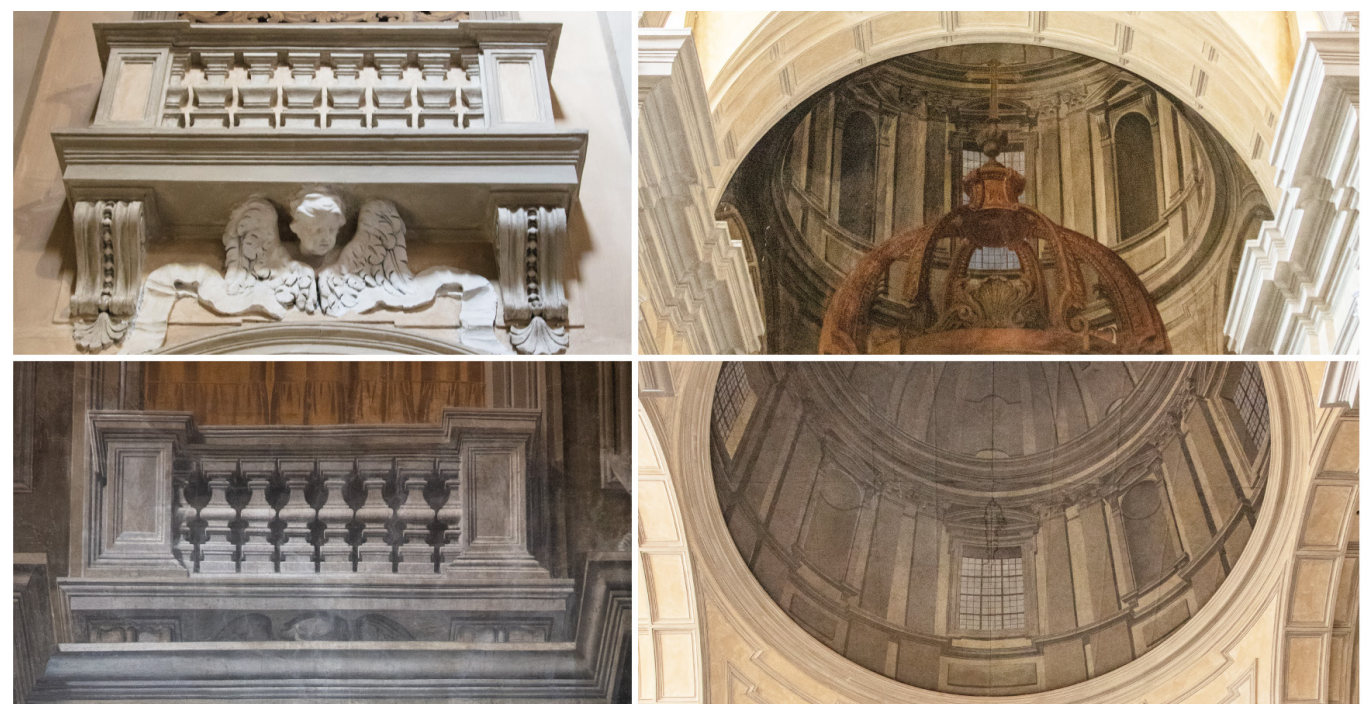
Fig. 7. Perspective analysis of the church of Gesu
in Frascati: (on the left) plan with the positioning of the point of view

and the overturning of

the elevations; (on the

right) axonometric view

illustrating the procedure

adopted to identify the

points of view.

Fig. 8. The union between real space and illusory

analyzed cases: the chapel

of the Vigna (a); the

corridor of the rooms

of Sant' Ignazio (b); the
church of Gesù in Frascati

(c)
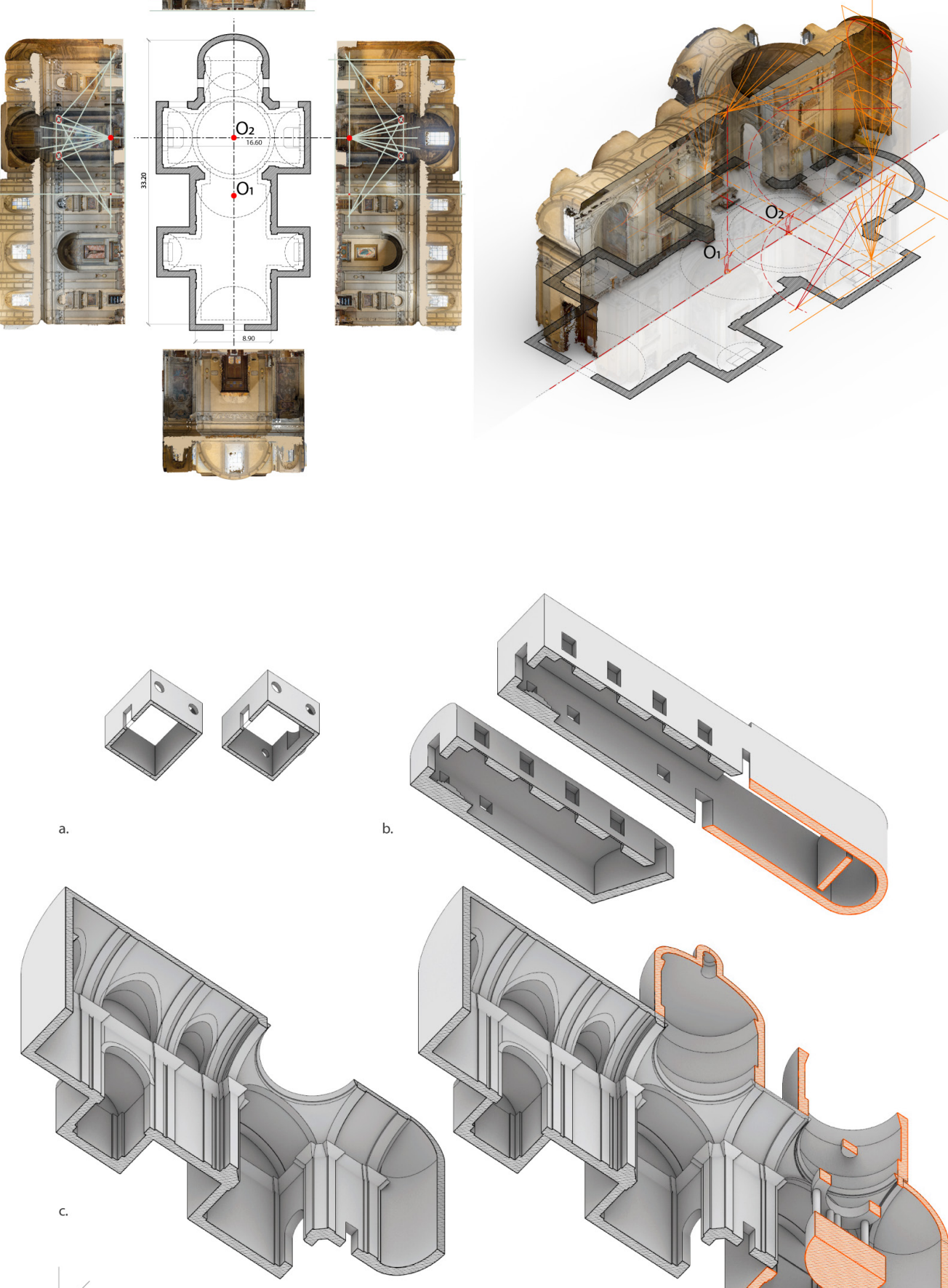

K

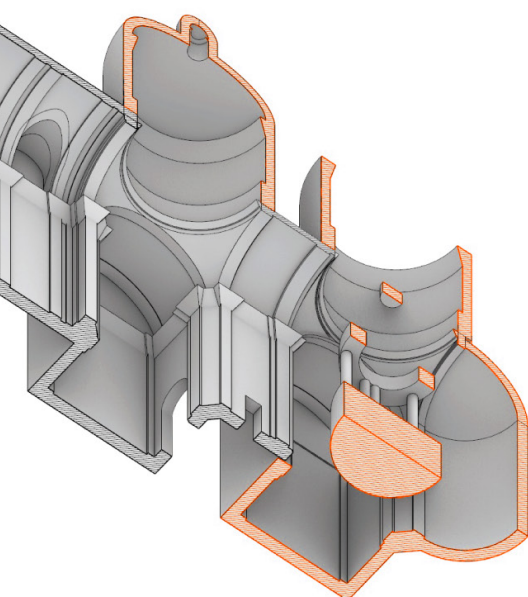




\section{Conclusions}

The analyses conducted on the three artworks reveal the figure of an artist who is more versatile than what emerges from the individual artistic experiences. Pozzo appears capable not only of designing illusory architectures that are compositionally and stylistically appropriate for the different spaces where he operates but also of adapting the perspective settings of each illusion to the characteristics of the place. In fact, it emerges the ability to vary the design of the 'quadratura' using one or more points of view, and to implement different design operations that, from time to time, establish a precise relationship between real architecture and illusory architecture: an intervention only aimed at the wall surface of the chapel of the Vigna; an articulated intervention, in which the layout of the surfaces, the breakthroughs that open to spatial additions and the anamorphic transmutation of the form dialogue in a unified continuum in the Corridor of the rooms of Sant'lgnazio and, finally, one with multiple openings and spatial additions, with the inclusion of decorative elements otherwise absent, at the Gesù in Frascati [7] (fig. 8).

These conclusive considerations can be synthetically represented in a graph that relates the considered analysis criteria -typology of the real space involved, number of points of view adopted and type of compositional intervention chosen by Pozzo- and integrates other works by the Trentino artist taking from the extensive bibliography [Bergamo, Calandriello 20 I9; Dardanello 20 I; Vallespìn 20 I4; Russo 1996; Bösel, Salviucci Insolera 2009] [8] (fig. 9). The graph highlights the variety of geometric and compositional approaches adopted by Pozzo with some constants: the adoption of several points of view in large subjects and the introduction of anamorphic-transformative effects in the case of small vaulted subjects. The developments of the study intend to expand the case study analysed by subjecting the entire corpus of Andrea Pozzo's quadratura works to the analytical method presented here [9].

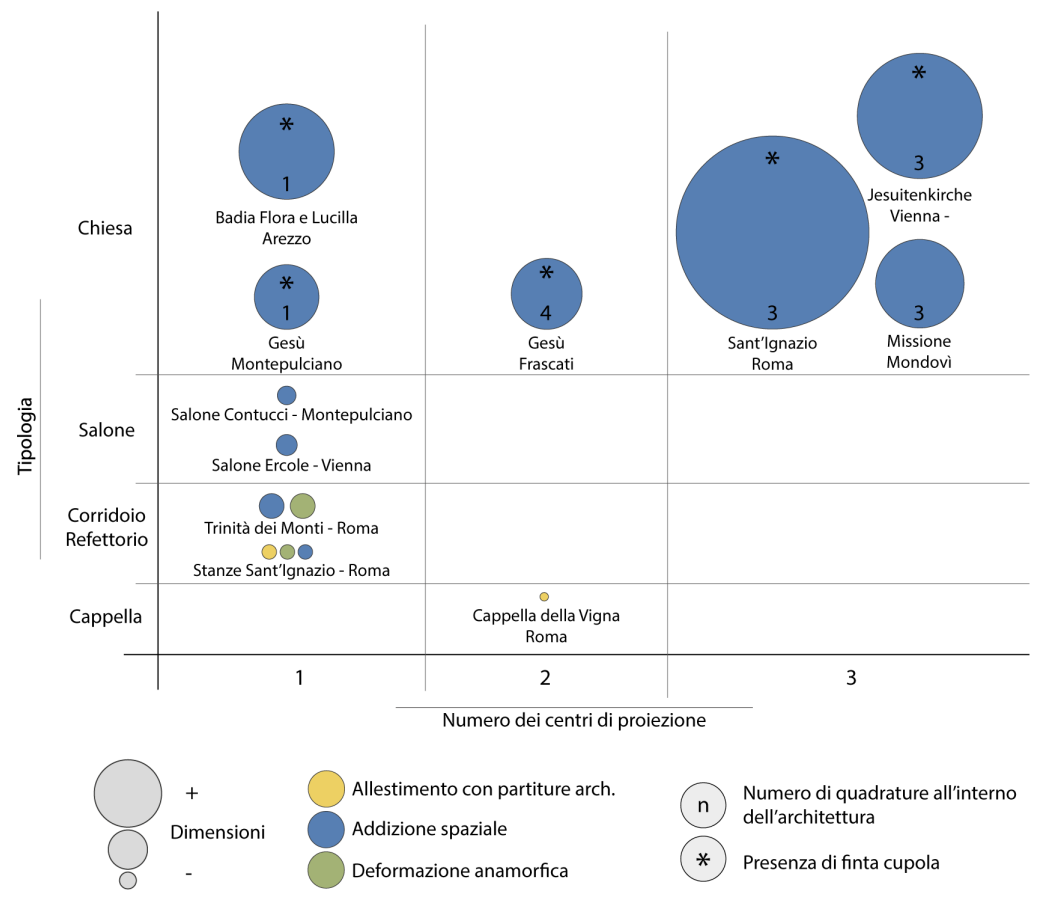

Notes

[I]The convent, after the closure of the Jesuit Order in 1773, passed to the Order of Frati Minori Conventuali. For allowing the photographic and photogrammetric survey of the chapel, we thank the guardian Padre Franklin. We also thank Padre Campelo.

[2] The Chapel of the Vigna represents an important place in Ignatian hagiography; in fact, the Saint would have lived in that very room the last days of his illness, before being transferred to the house of Gesù in Rome.

[3] For an accurate perspective restitution of the individual architectural and decorative elements see: Romor 2019, pp. 191203; Sdegno, Romor 2008 
[4] The prospective restitution of the main frescoed elements on the surfaces showed a height of $1.56 \mathrm{~m}$.

[5] An excerpt from the biography of F. Baldinucci: : "impercioché essendo la chiesa molto corta, volle colla sua prospettiva farla apparire quasi per la metà piü lunga" [Benvenuti 1912, pp. 230]

[6] Choice already made in the church of Sant'lgnazio in Rome.

[7] The 3d models highlight only interventions that introduce changes in the volume of the rooms. The decorative elements introduced through the "quadratura" have not been represented to help a better understanding of the spatial and compositional operations.

[8] Three projection centres are considered for the church of Sant'Ignazio di Loyola: one for the Glory of Sant'Ignazio, one for the false dome and one for the apse basin. For the church of Gesù in Montepulciano, two projection centres were taken into consideration: one for the false dome, one for the altars of the right and left chapels. In the latter case, it is specified that no preferential viewpoint is indicated on the floor.

[9] The quote in the title is thaken from Figura Trentesimanona of the of the Trattato [Pozzo 1693].

\section{References}

Battisti Alberta (1996). L'azione spaziale di Andrea Pozzo. In Battisti Alberta (a cura di). Andrea Pozzo. Milano-Trento: Luni Editrice, pp. 49-55

Benvenuti Emilio (19|2). La vita del Padre Andrea Pozzo scritta da Francesco Baldinucci. In AA.W. Atti della I. R. Accademia di Scienze lettere ed arti degli agiati in Rovereto, serie III, vol. XVIII, Fascicolo II. Rovereto:Tipografia Ugo Grandi, pp. 230.

Bergamo Francesco, Calandriello Antonio (2019). Andrea Pozzo e la quadratura del Refettorio: tra rigore prospettico e licenza poetica. In De Rosa Agostino (a cura di). Roma anamorfica: prospettiva e anamorfosi in epoca barocca. Roma: Aracne Editrice, pp. $18-34$.

Bösel Richard, Salviucci Insolera Lydia (2009). Cronologia commentata della vita e delle opere di Andrea Pozzo. In Bösel Richard, Salviucci Insolera Lydia (a cura di). Mirabili disinganni. Andrea Pozzo (Trento 1642-Vienna 1709). Pittore e architetto gesuita. Roma: Artemide, pp. 293-300.

Bösel Richard, Salviucci Insolera Lydia (a cura di). (2009). Mirabili disinganni. Andrea Pozzo (Trento I642-Vienna 1 709). Pittore e architetto gesuita. Roma: Artemide.

Carta Marina (1996). Le finte cupole. In De Feo Vittorio, Martinelli Valentino (a cura di). Andrea Pozzo. Milano: Electa, pp. 54-65.

Dardanello Giuseppe (2009). I 2.07 Mondovì, Chiesa della Missione (già S. Francesco Saverio). Rilievo dell'architettura costruita e delle prospettive dipinte da Andrea Pozzo. In Bösel Richard, Salviucci Insolera Lydia (a cura di). Mirabili disinganni.Andrea Pozzo (Trento 1642 - Vienna 1 709). Pittore e architetto gesuita. Roma: Artemide, pp. 256-258.

Gallavotti Daniela (1996). Gli esordi pittorici a Roma: il corridoio del Gesù e la cappella della Vigna. In De Feo Vittorio, Martinelli Valentino (a cura di). Andrea Pozzo. Milano: Electa, pp. 42-53.

Migliari Riccardo (a cura di). (1999). La costruzione dell'architettura illusoria. Roma: Gangemi editore.

Pipita Giuseppe (2013). La chiesa del Gesù a Frascati - Pitture di Andrea Pozzo. e-book LULU, 2013.

Pozzo Andrea (1 693). Perspectiva pictorum et architectorum, vol. I. Roma: Joannes Jacob Komarek.

Pozzo Andrea ( 1700). Perspectiva pictorum et architectorum, vol. II. Roma: Joannes Jacob Komarek.

Romor Jessica (2019). Andrea Pozzo e il corridoio della Casa Professa del Gesù. In De Rosa Agostino (a cura di). Roma anamorfica: prospettiva e anamorfosi in epoca barocca. Roma: Aracne Editrice, pp. 191-203.

Russo Maria (1996). Il salone delle Feste di Palazzo Contucci a Montepulciano. In Battisti Alberta (a cura di). Andrea Pozzo. Milano-Trento: Luni Editrice, 281-296.

Sdegno Alberto, Romor Jessica (2008). Percezione e restituzione degli affreschi di Andrea Pozzo presso le Stanze di S. Ignazio a Roma. In Disegnare Idee Immagini, n. 37, pp. 48-57.

Vallespín Muniesa Aurelio (20।4). La modificaciòn del espacio arquitectònico a través de la perspectiva: la intervenciòn de Andrea Pozzo en la iglesia de los Jesuitas de Viena. In EGA Revista de Expression Grafica Arquitectonica, n. I9, pp. 200-209

\section{Authors}

Antonio Camassa, Università degli Studi RomaTre, antonio.camassa@uniroma3.it

Matteo Flavio Mancini, Università degli Studi RomaTre, matteoflavio.mancini@uniroma3.it

To cite this chapter. Camassa Antonio, Mancini Matteo Flavio (2020). 'Se [...] vi venisse voglia di mutare per un po' di tempo la forma dell'architettura". II progetto dellillusione di Andrea Pozzo in tre opere romane/" "Se [...] vi venisse voglia di mutare per un po' di tempo la forma dell'architettura". The project of illusion by Andrea Pozzo in three Roman works. In Arena A., Arena M., Brandolino R.G., Colistra D., Ginex G., Mediat D., Nucifora S., Raffa P. (a cura di). Connettere. Un disegno per annodare e tessere. Atti del $42^{\circ}$ Convegno Internazionale dei Docenti delle Discipline della Rappresentazione/Connecting. Drawing for weaving relationships. Proceedings of the 42th International Conference of Representation Disciplines Teachers. Milano: FrancoAngeli, pp. 1017-1034. 